\title{
THE ACCOUNTING TREATMENT OF SINGLE-COMPANY CLIENT LOYALTY PROGRAMME TRANSACTIONS
}

\author{
Sophia Brink* \\ Stellenbosch University \\ sophiabrink@sun.ac.za
}

Received: February 2013

Accepted: August 2013

\begin{abstract}
Client loyalty programmes have been prevalent in South Africa since the 1980s, but the popularity of these programmes has increased drastically over the past few years, with more than 100 suppliers in South Africa currently making use of them. On 1 July 2007 the IASB issued IFRIC 13 to give specific guidance to suppliers on the accounting treatment of client loyalty programme transactions. The IASB is currently compiling a new revenue standard. This single new revenue standard will replace six existing standards or interpretations, including IFRIC 13. A critical analysis of IFRIC 13 will assist the development of this new revenue standard. The main objective of the research was therefore to determine whether the guidance in IFRIC 13 regarding the accounting treatment of a single-company client loyalty programme transaction is consistent with other accounting standards and recent developments. The accounting treatment of each component of a client loyalty programme transaction with a change in estimate was considered. It was found that inconsistencies exist in the initial measurement of the fair value and how a change in accounting estimate is recognised.
\end{abstract}

Keywords

Client loyalty programmes, IFRIC 13, new revenue standard.

*Ms Sophia Brink is a lecturer in the Department of Accounting, Stellenbosch University, South Africa. 


\section{BACKGROUND AND FORMULATION OF THE STUDY}

\subsection{Background}

A client loyalty programme can be defined as a programme where consumers accumulate free points or miles based on the purchases of goods or services from a supplier. The consumer can exchange these points or miles for a variety of commodities (including goods, services or a discount on a next purchase transaction) at a supplier (Liu, 2007). The popularity of client loyalty programmes has increased drastically (Travel wires, 2011), and more than 100 suppliers in South Africa are already making use of these programmes (Conradie, 2011). On 1 July 2007 the International Accounting Standards Board (IASB) issued the Interpretation of International Financial Reporting Interpretation Committee (IFRIC) 13 to give specific guidance to suppliers on the accounting treatment of client loyalty programme transactions. This Interpretation has been applied by suppliers with annual periods beginning on or after l July 2008. The IASB is currently compiling a new revenue standard. This standard is intended to replace IAS 11 Construction Contracts, IAS 18 Revenue, IFRIC 13 Customer Loyalty Programmes, IFRIC 15 Agreements for the Construction of Real Estate, IFRIC 18 Transfers of Assets from Customers and SIC 31 Revenue - Barter Transactions Involving Advertising Services (KPMG, 2011:4). All comments on the second exposure draft "Revenue from contracts with customers" which were received by 13 March 2012 (Ernst \& Young, 2011) are currently under consideration.

\subsection{Research problem}

All International Financial Reporting Standards (IFRS) should give consistent guidance on how to account for a specific transaction. This will meet the objective of the IASB to develop a single set of high quality, understandable, enforceable and globally accepted financial reporting standards based on clearly articulated principles (Preface to International Financial Reporting Standards: par 6(a)). The IASB is committed to promoting harmonisation of all accounting standards.

The new revenue standard is intended to supersede virtually all existing revenue standards and interpretations under IFRS (Ernst \& Young, 2012). The IASB intends to design the new revenue standard to streamline accounting for revenue across all industries and to correct inconsistencies in existing standards and practices (Lamareaux, 2012). It is not certain whether the guidance provided in IFRIC 13 is consistent with other accounting standards or adequately updated with new standards issued.

\subsection{Research objective and methodology}

The new revenue standard will replace IFRIC 13. Before developing a new standard it is important to consider the existing guidance. A critical analysis of IFRIC 13 is therefore crucial in the development of this new revenue standard. In order to evaluate the thought process of the IASB in the original drafting and subsequent amendments to IFRIC 13 and to identify any shortcomings, IFRIC 13 can be compared with other accounting standards and recent developments.

The main objective of the research was therefore to determine whether the guidance in IFRIC 13 regarding the accounting treatment of a client loyalty programme transaction is consistent with 
other accounting standards and recent developments. In order to meet this objective the following research questions were addressed:

- Is the guidance in IFRIC 13 regarding the accounting treatment of a change in accounting estimate consistent with International Accounting Standards (IAS) 8?

- What is the correct accounting treatment of the liability (deferred revenue) referred to in International Financial Reporting Interpretation Committee (IFRIC) 13?

- Is the fair value measurement in IFRIC 13 consistent with the requirements of International Financial Reporting Standards (IFRS) 13?

In conducting this study it was decided that only single-company programmes would be focused on, as this was an initial study and otherwise the scope of the study would be too wide. Another reason for this decision was that single-company programmes are the simplest form of client loyalty programmes. In the South African market single-company programmes are also the most popular client loyalty programme with reference to known active membership numbers (Conradie, 2007). The scope of this research was therefore limited to single-company programmes. The other two categories of client loyalty programmes (single-company dominated programmes and a multi-partner programmes) were therefore not considered in this research.

In order to evaluate the accounting treatment of a single-company client loyalty programme transaction it was important to obtain an understanding of the functioning of these programmes. Taking into consideration the functioning of single-company client loyalty programmes, the available literature was analysed to determine what the proposed treatment of a single-company client loyalty programme transaction with a change in accounting estimate in terms of IFRIC 13 entails. This proposed treatment was compared with relevant standards to determine whether consistency exists.

\subsection{Research contribution}

A contribution of the research is that it assessed the correctness of IFRIC 13, which specifically deals with client loyalty programme transactions, with reference to other relevant standards. Where it was found that insufficient and incorrect guidance is provided, inconsistencies are highlighted in this article and the proposed accounting treatment of a single-company client loyalty programme transaction where a change in accounting estimate occurs is provided. The IASB is currently compiling a new revenue standard that will replace IFRIC 13. The research is especially relevant in the light of this new standard and can be considered in the development of this new standard.

\section{THE DEFINITIONS AND FUNCTIONING OF CLIENT LOYALTY PROGRAMMES}

Section 1 of the Consumer Protection Act No. 68 of 2008 defines the term 'loyalty' as follows:

any arrangement or scheme in the ordinary course of business, in terms of which a supplier of goods or services ... offers or grants to a consumer any loyalty credit or award in connection with a transaction or an agreement

The basic functioning of client loyalty programmes is as follows: members of the general public can apply for membership by completing an application form where personal information is provided. Approved members will be issued with a membership card that should be scanned during each purchase transaction in order for them to accumulate client loyalty programme 
points or miles. A magnetic strip on the back of the membership card collects the details of the items purchased, together with the points or miles that are granted (Maharaj, 2008). The points or miles accumulated on the membership card may later be exchanged for goods, services or a discount on goods or services during a following purchase transaction.

\section{ANALYSIS OF INTERNATIONAL FINANCIAL REPORTING STANDARDS}

In a client loyalty programme transaction points are granted by the supplier to the consumer as part of a normal revenue transaction. These points give the consumer a right to future benefits in the form of goods, services or discounts (benefits). The points granted create the obligation for the supplier to supply future benefits for compensation already received. The compensation received is for the goods or services delivered in the current transaction and for benefits to be delivered in the future.

In order to account for this compensation the supplier should consider accounting standard IAS 18 , which deals with the accounting treatment of revenue. When dealing specifically with client loyalty programme transactions IFRIC 13 should be applied.

\subsection{The accounting treatment required by IFRIC 13 (read together with IAS 18)}

IFRIC 13 deals with client loyalty programmes and applies to points that:

- a supplier grants to consumers as part of a revenue transaction; and

- subject to meeting any further qualifying conditions, enables consumers to claim goods or services in the future for free or at a discount (IFRIC 13, paragraph 3).

The interpretation provides guidance on the accounting treatment of a client loyalty programme transaction by the supplier that grants points to its consumers. Consensus was reached regarding uncertainties about the measurement and recognition of points. This aspect is discussed in IFRIC 13.

Under IFRIC 13 different measurement and recognition requirements exist based on whether the obligation to supply benefits rests on the supplier itself or whether the obligation to supply benefits rests on a third party. The scope of this research is limited to single-company client loyalty programmes, and consequently client loyalty programmes where the obligation to supply benefits rests on a third party falls outside the scope of this research.

Paragraph 5 of IFRIC 13 states that the supplier must apply paragraph 13 of IAS 18 to recognise the consideration received. IAS 18 deals with the accounting treatment of revenue arising from the sale of goods, the rendering of services and the use by others of entity assets yielding interest, royalties and dividends. Paragraph 13 of IAS 18 states that the accounting treatment in IAS 18 is usually applied separately to each transaction. In certain circumstances it is necessary to apply the accounting treatment to the separately identifiable components of a single transaction in order to reflect the true substance of the transaction. For example, when the selling price of a product includes an identifiable amount for subsequent servicing, that amount is deferred and recognised as revenue over the period during which the service is rendered. 
A client loyalty programme transaction may be regarded as a single transaction consisting of two separate identifiable components, namely the sale of goods or services, and the granting of points that gives the consumer a right to benefits.

In terms of paragraph 13, the accounting treatment must be applied separately to each of the components in the transaction. The points granted are linked to an identifiable amount or value, i.e. the value of the benefits receivable by the consumer in the future. The selling price therefore includes an identifiable amount for the future supplying of benefits. A client loyalty programme transaction is thus similar to the example referred to in paragraph 13 of IAS 18 (a sales transaction where the selling price includes an amount for subsequent servicing). The consideration received or receivable from the sale should be allocated to the goods or services sold and the points granted. The portion allocated to the goods or services sold will be recognised as revenue during the sales transaction. The portion allocated to the points will be recognised as revenue only when the points are exchanged for benefits, and the recognition of this portion of the revenue is therefore deferred.

Paragraph 5 of IFRIC 13 further states that the fair value of the consideration received or receivable under the initial sale must be allocated between the points and the other components of the sale. Paragraph 6 of IFRIC 13 states that the portion of consideration allocated to the points granted in the underlying sales transaction shall be measured by reference to their fair value.

The Application Guidance to IFRIC 13 (which is considered to be an integral part of the interpretation) provides guidance on determining the fair value. Paragraph 1 of IFRIC 13 Application Guidance (hereafter referred to as $A G$ ), states that if there is not a quoted market price for an identical point, fair value must be measured using another valuation technique. The supplier may measure the fair value of points with reference to the fair value of the benefits they could be exchanged for - in other words, the value of the points in the hands of the consumer. The fair value of the points takes into account, as appropriate:

- the amount of the discounts or incentives that would otherwise be offered to consumers who have not earned points from an initial sale;

- the proportion of points that are not expected to be exchanged by consumers; and

- non-performance risk (IFRIC 13, AG paragraph 2).

If consumers can choose from a range of different benefits, the fair value of the points reflects the fair values of the range of available benefits, weighted in proportion to the frequency with which each benefit is expected to be selected (IFRIC 13, AG paragraph 2). In some circumstances, other valuation techniques may be used to determine the fair value. Judgement is required to select and apply the valuation technique that is most appropriate in the circumstances (IFRIC 13, AG paragraph 3).

Paragraph 7 of IFRIC 13 states that if a supplier supplies the benefits itself, it shall recognise the consideration allocated to points as revenue when points are exchanged and the supplier fulfils its obligation to supply benefits. The amount of revenue recognised shall be based on the number of points that have been exchanged for benefits, relative to the total number expected to be exchanged. 


\subsection{Is the guidance in IFRIC 13 regarding the accounting treatment of a change in accounting estimate consistent with IAS 8?}

IAS 8 deals with accounting policies, changes in accounting estimates and errors. This standard will apply to a client loyalty programme transaction if a change in accounting estimate occurs in respect of the number of points expected to be exchanged.

The Basis for Conclusions on IFRIC 13 (which is considered to be an integral part of the interpretation) that accompanies IFRIC 13 deals among other things with the change in accounting estimate in respect of points granted. IFRIC 13 Basis for Conclusions (hereafter referred to as BC) paragraph 16 states that, after granting points, the supplier may revise its expectation about the number of points that will be exchanged. The change in expectation does not affect the consideration that the supplier has received for supplying benefits (this consideration was fixed at the time of the initial sale). Per IFRIC 13 the change in expectation therefore does not affect the measurement of the original liability. Instead, it affects the amount of revenue recognised in respect of points that are exchanged in the period (although the original expectation was used in determining the fair value). IFRIC 13, therefore, determines that the deferred revenue (the amount in the statement of financial position) should not be adjusted for a change in estimate, but rather that the rate at which the deferred revenue is recognised to profit and loss should be adjusted.

IAS 8 paragraph 36 states that the effect of a change in an accounting estimate, other than a change to which paragraph 37 applies, shall be recognised prospectively by including it in profit or loss in the period of the change, if the change affects that period only or the period of the change and future periods, if the change affects both. To the extent that a change in an accounting estimate gives rise to changes in assets and liabilities, or relates to an item of equity, it shall be recognised by adjusting the carrying amount of the related asset, liability or equity item in the period of the change (IAS 8, paragraph 37).

While it is correct to say that the change in expectations does not affect the consideration that the supplier has received for supplying benefits, the question arises whether the liability must be adjusted to accommodate the change in accounting estimate. This will be investigated by analysing the illustrative example of IFRIC 13.

\subsection{Critical analysis of IFRIC 13's illustrative example}

IFRIC 13 is accompanied by illustrative examples to assist the supplier in the application of this interpretation. The following example is one of the two examples included in the interpretation and deals with a single-company programme where the obligation to supply benefits rests on the supplier. The scenario in the illustrative example is as follows.

A grocery retailer operates a single-company client loyalty programme. It grants consumers points when they spend a specified amount on groceries. Points accumulate on the membership card and are not subject to an expiry date. Consumers can redeem the accumulated points for further groceries. In year one, the supplier grants 100 points. Management measures the fair value of groceries for which each point can be redeemed as Rl,25. Management expects that only 80 of the 100 points will be exchanged. This can be determined with reference to the rate at which points were exchanged in the past, i.e. the historical exchange rate (PricewaterhouseCoopers, 2009). The supplier can determine the fair value allocated to the points with reference to the value of the points (in the hands of the consumer) multiplied by the 
expectation of points that will be exchanged. Therefore the fair value of each point can be calculated as Rl ( 80 points $/ 100$ points $\times \mathrm{Rl} .25=\mathrm{Rl}$ ). At the end of year one 40 points were exchanged for goods worth R50 (40 points $\times$ R1.25), i.e. half of those expected to be redeemed.

During year one the grocery retailer will recognise a liability (deferred revenue) of R100 (being the fair value allocated to the points) and at the end of year one will derecognise R50 of the liability (deferred revenue) and recognise revenue of R50 (40/80 × R100). See the journal entries in year one in TABLE 1 .

Management's expectation regarding the number of points that will be exchanged change in year two. Management now expects that 90 points in total will be exchanged. During year two, 41 points are exchanged and goods worth R51.25 are supplied. The cumulative number of points exchanged at the end of year two equals 81 points. The cumulative revenue that the grocery retailer recognises is $\mathrm{R} 90$ [( 81 points $/ 90$ points $) \times R 100$ ]. The grocery retailer already recognised revenue of $\mathrm{R} 50$ in year one, so it recognises R40 in year two. Management's expectation remains unchanged during year three and they continue to expect 90 points in total to be exchanged. In line with management's expectations, 9 points are exchanged during year three for goods worth R11.25. The cumulative number of points exchanged at the end of year three equals 90 points. The cumulative revenue to date is $R 100$ [(90 points/90 points $) \times R 100$ ]. The grocery retailer already recognised revenue of $\mathrm{R} 50$ in year one and $\mathrm{R} 40$ in year two. The grocery retailer will therefore recognise the remaining R10 in year three, and all the revenue initially deferred has now been recognised. See the journal entries in years two and three in TABLE 1.

TABLE 1: General journal entries of the grocery retailer

\begin{tabular}{|c|c|c|c|}
\hline Date & Journal entry & Debit & Credit \\
\hline \multirow[t]{8}{*}{ Year 1} & Bank & 1000 & \\
\hline & Revenue & & 900 \\
\hline & Liability (deferred revenue) & & 100 \\
\hline & (Fair value allocated to points: R1.25 × $80 \% \times 100$ points) & & \\
\hline & Liability (deferred revenue) & 50 & \\
\hline & Revenue & & 50 \\
\hline & {$[(40$ points $/ 80$ points $\times R 100)$} & & \\
\hline & Or 40 points $\times R 1.25$ (value of the benefits supplied)] & & \\
\hline \multirow[t]{3}{*}{ year 2} & Liability (deferred revenue) & 40 & \\
\hline & Revenue & & 40 \\
\hline & $(81$ points $/ 90$ points $\times$ R100) -50 & & \\
\hline \multirow[t]{3}{*}{ Year 3} & Liability (deferred revenue) & 10 & \\
\hline & Revenue & & 10 \\
\hline & (90 points $/ 80$ points $\times R 100)-50-40$ & & \\
\hline
\end{tabular}

Source: Author's analysis 
The journal entries in TABLE 1 are based on the guidance in IFRIC 13 and illustrate the accounting entries of the above transaction in the general journal of the grocery retailer.

Note that even though the value of the points exchanged and the value of the benefits supplied in year two equal R51.25 (41 points $\times$ R1.25), only R40's revenue is recognised. In year three, the value of the points exchanged and the value of the benefits supplied equals R11.25 (R1.25 $\times$ 9 points) and only R10's revenue is recognised. The question arises whether the balance (Rand amount) of the liability (deferred revenue) should be changed to accommodate the change in expectation. At the beginning of year two, the balance of the liability (deferred revenue) equals R50. In year two, there is now an expectation that another 50 points ( 90 points minus 40 points already exchanged) to the value of R1.25 each will be exchanged in the future. The fair value of the liability (deferred revenue) is therefore R62.50 (50 points $\times$ R1.25), which is R12.50 more than the value of the current liability (deferred revenue). If the liability (deferred revenue) is adjusted, the revenue recognised in the future will be in line with the value of the points exchanged and the value of the benefits supplied.

IFRIC 13 provides specific guidance to the supplier about determining the fair value that should be allocated to the points. The only guidance given in respect of a change in accounting estimate is found in the illustrative example and in IFRIC 13 BC that accompanies the interpretation. As already discussed, IFRIC $13 \mathrm{BC}$ paragraph 16 determines that the change in estimate does not affect the original liability and therefore it should not be changed. The example also illustrates this principle by not adjusting the liability (deferred revenue) to accommodate the change in estimate. The interpretation seems to imply that the value allocated to the points must be measured at fair value only with the initial transaction, after which no adjustments are made even if the fair value changes. The possibility that the liability must be adjusted to accommodate the change in accounting estimate and consequently not be treated as deferred revenue should be investigated.

\subsection{What is the correct accounting treatment of the liability (deferred revenue) referred to in IFRIC 13 ?}

IFRIC 13 deals mainly with the recognition and measurement of the revenue component of the client loyalty programme transaction. The question arises how the other components of the transaction should be treated.

Prior to the issue of IFRIC 13 it was common practice to account for the cost of providing future benefits as an expense (applying paragraph 19 of IAS 18), recognised on the date of sale and recognising a provision in accordance with IAS 37. This accounting treatment is in line with the first view discussed in the IFRIC 13 BC. This view to recognise a separate expense was rejected because points granted are not costs that directly relate to the goods and services already delivered - rather, they are separate goods or services delivered in the future.

Paragraph 7 of IFRIC 13 BC explains the excepted second view. This paragraph states that a part of the consideration received in respect of the initial sale should be allocated to the points and recognised as a liability until the entity fulfils its obligations to deliver benefits to customers. IFRIC 13 classifies this liability as deferred revenue.

A discrepancy was found in IFRIC 13, which states that the portion of consideration allocated to the points granted (liability) shall be measured by reference to their fair value. This liability (deferred revenue) should not be adjusted to accommodate a change in estimate and therefore 
should not be adjusted to reflect the fair value of the liability. Classifying the liability as deferred revenue, the portion of consideration allocated to the points granted with a change in estimate will no longer be measured at fair value. The classification of the liability was therefore investigated.

\section{Classification}

IAS 37 deals with the accounting treatment of provisions, contingent liabilities and contingent assets. According to paragraph 10 of IAS 37 a liability can be defined as "a present obligation of the entity arising from past events, the settlement of which is expected to result in an outflow from the entity of resources embodying economic benefits."

For a liability to arise, an obligating event (previous event that leads to a present obligation) must occur. An obligating event is an event that creates a legal or constructive obligation that results in an entity having no realistic alternative to settling that obligation. A legal obligation is an obligation that derives from a contract, legislation or other legal operation of law, while a constructive obligation is an obligation that derives from an entity's actions where:

- by an established pattern of past practice, published policies or a sufficiently specific current statement, the entity has indicated to other parties that it will accept certain responsibilities; and

- as a result, the entity has created a valid expectation on the part of those other parties that it will discharge those responsibilities.

Based on the examination of the terms and conditions of single-company programmes the following characteristic will possibly influence the classification of the deferred revenue: the form in which points are received. Therefore in order to apply IAS 37's definition of a liability on a client loyalty programme transaction, the benefits of the programmes are categorised as follows:

- Points that accumulate on the membership card

- Points earned issued in the form of a cash back reward

\section{Points that accumulate on the membership card}

In client loyalty programmes where points accumulate on the membership card, the consumer will have access to the points as they are earned and accumulate on the membership card. These client loyalty programme points can be subject to an expiry date or not.

Points granted can be measured against the definition of a liability as follows: when the supplier grants points to a consumer, a present obligation arises in the hands of the supplier to supply benefits to the consumer with the exchange of these points. The original sale and granting of the points indicates the event in the past. When the consumer exchanges points and the supplier supplies benefits an outflow of economic benefits will occur because goods, services or a discount is given by the supplier. The obligating event indicates a legal obligation under the terms and conditions of the client loyalty programme application form which provides that benefits will be supplied when the consumer exchanges points (before the expiry date, if applicable). It can be seen as an agreement or contract between the supplier and the consumer. The obligating event may also be seen as a constructive obligation, because it is the supplier's practice to supply benefits when the consumer exchanges points (before the expiry date, if applicable). The deferred revenue therefore meets the requirements of the definition of a liability. 


\section{Points earned issued in the form of a cash back reward}

In client loyalty programmes where cash back rewards are issued, the consumers obtain access to the accumulated points only once the cash back reward is issued by the supplier. These client loyalty programme points can be subject to an expiry date or not. In the South African client loyalty programmes investigated, where cash back rewards are issued the cash back reward was subject to an expiry date and issued quarterly in respect of accumulated points.

Points granted that will later form part of the cash back reward can be measured against the definition of a liability as follows: when the supplier grants points to a consumer, a present obligation arises in the hands of the supplier to issue a cash back reward for these points to the consumer, if the consumer accumulates enough points (before the expiry date, if applicable). The original sale and granting of the points indicates the event in the past. When the consumer accumulates enough points, a cash back reward is issued, and if it is exchanged (in time, before the expiry date) the supplier supplies benefits and an outflow of economic benefits will occur, because goods, services or a discount is given by the supplier. The deferred revenue therefore meets the requirements of the definition of a liability. When considering if a cash back reward issued meets the definition of a liability the same reasoning can be followed as for the points initially granted as discussed above.

The deferred revenue arising in a client loyalty programme transaction meets the definition of a liability. In order to determine the type of liability that arises, the following definitions are considered: IAS 32 defines a financial liability as "any liability that is a contractual obligation to deliver cash or another financial asset to another entity ..." In a client loyalty programme transaction a contractual obligation arises to supply goods or services and not cash or a financial asset. The liability that arises in a client loyalty programme transaction does not meet the definition of a financial liability.

Paragraph 10 of IAS 37 defines a provision as follows: a provision can be defined as a liability of uncertain timing or amount. Therefore a liability (as defined above) must be present for any provision to exist. To apply IAS 37's definition of a provision on a client loyalty programme transaction the two categories of client loyalty programmes are considered.

\section{Points that accumulate on the membership card}

The points granted meet the definition of a provision based on the following: a liability occurs (as discussed above) and the timing and amount are uncertain, as there is no certainty about when or whether the consumer will exchange the points. The requirements of the definition of a provision (provision for the supplying of benefits) are therefore met.

\section{Points earned issued in the form of a cash back reward}

The points granted meet the definition of a provision based on the following: a liability occurs (as discussed above) and the timing and amount are uncertain, as there is no certainty about when or whether the consumer will accumulate enough points to qualify for a cash back reward. The requirements of the definition of a provision (provision for the supplying of a cash back reward) are therefore met.

The cash back rewards issued meet the definition of a provision based on the following: a liability occurs (as discussed above) and the timing and amount is uncertain, as there is no certainty about when or whether the consumer will exchange the cash back rewards. The requirements of the definition of a provision (provision for the supplying of benefits) are therefore met. 
The deferred revenue arising in a client loyalty programme transaction meets the definition of a provision. The measurement of this provision in terms of IAS 37 can now be compared with the measurement of the liability (deferred revenue) in terms of IFRIC 13.

\section{Measurement}

IAS 37 paragraphs 36-42 provide clear guidelines on the measurement of a provision. The amount recognised as a provision shall be the best estimate of the expenditure required to settle the present obligation at the end of the reporting period or to transfer it to a third party at that time (IAS 37, paragraphs 36 and 37). The estimates of outcome and financial effect are determined by the judgement of the management of the entity, supplemented by experience of similar transactions and, in some cases, reports from independent experts. The evidence considered includes any additional evidence provided by events after the reporting period (IAS 37, paragraph 38). Uncertainties surrounding the amount to be recognised as a provision are dealt with by various means according to the circumstances. Where the provision being measured involves a large population of items, the obligation is estimated by weighting all possible outcomes by their associated probabilities. The name for this statistical method of estimation is 'expected value' (IAS 37, paragraph 39). The risks and uncertainties that inevitably surround many events and circumstances shall be taken into account in reaching the best estimate of a provision (IAS 37, paragraph 42). TABLE 2 illustrates IAS 37 and IFRIC 13's guidelines in determining the value of the deferred revenue (provision).

TABLE 2: IAS 37 and IFRIC 13's guidelines on determining the value of the deferred revenue (provision)

The amount recognised as a provision shall be the best estimate of the expenditure required to settle the present obligation at the end of the reporting period or to transfer it to a third party at that time (paragraph 36 and 37 ). The value of the liability is therefore measured from the perspective of the supplier.

Where the provision being measured involves a large population of items, the obligation is estimated by weighting all possible outcomes by their associated probabilities (paragraph 39).

The risks and uncertainties that inevitably surround many events and circumstances shall be taken into account in reaching the best estimate of a provision (paragraph 42).
If there is not a quoted market price for an identical point, fair value must be measured using another valuation technique. The supplier may measure the fair value of points by reference to the fair value of the benefits they could be exchanged for (AG, paragraph 1 ). In other words, the value of the points (held as an asset) in the hands of the consumer.

If consumers can choose from a range of different benefits, the fair value of the points reflects the fair values of the range of available benefits, weighted in proportion to the frequency with which each benefit is expected to be selected (AG, paragraph 2).

The fair value of the points among other things takes into account non-performance risk ( $A G$, paragraph 2).

Source: Author's analysis

In summary, points and/or cash back rewards issued meet the definition of a provision. The measurement of this provision in terms of IAS 37 is in essence consistent with the requirements contained in IFRIC 13. The only differences noted are as follows: 
IAS 37 does not explicitly state whether or not credit risk should be taken into account. IAS 37 paragraph 42 refers only to "the risks and uncertainties that inevitably surround many events and circumstances", and paragraph 47 refers only to "the risks specific to the liabilities". During the March 2011 update the Interpretations Committee received a request for interpretation of this last-mentioned phrase. The Committee noted that this request for guidance would be best addressed as part of the Board's project to replace IAS 37 with a new liabilities standard.

IAS 37 determines the value of the provision from the perspective of the supplier (issuer) and IFRIC 13 determines the value of the liability (deferred revenue) from the perspective of the consumer.

IAS 37 does not refer to the value of the provision as the fair value.

\subsection{The effect of classifying the liability as a provision when a change in accounting estimate occurs}

According to IAS 37 paragraph 59 a provision must be reviewed at the end of each reporting period and adjusted to reflect the current best estimate. IAS 8 paragraph 37 states that to the extent that a change in an accounting estimate give rise to changes in liabilities it shall be recognised by adjusting the carrying amount of the related liability in the period of the change.

If the liability is recognised as a provision, the value allocated to the points will reflect the fair value (as required by IFRIC 13) even if a change in expectation occurs. The liability (provision) will be adjusted for changes in the accounting estimate that will ensure that the revenue recognised in the future will be in line with the value of the points exchanged and the value of the benefits supplied.

If the liability is recognised as a provision, a discrepancy arises between IFRIC 13 BC paragraph 16 , which states that the liability should not be adjusted with a change in estimate and IAS 37 paragraph 59 and IAS 8 paragraph 37, which in turn provide that the liability (provision) needs to be adjusted with a change in estimate.

TABLE 3 illustrates IAS 8 (together with IAS 37) and IFRIC 13's guidelines on the accounting treatment of a change in accounting estimate.

TABLE 3: IAS 8 (together with IAS 37) and IFRIC 13's guidelines on the accounting treatment of a change in accounting estimate

IAS 8 together with IAS 37

IFRIC 13

Provisions shall be reviewed at the end of each reporting period and adjusted to reflect the current best estimate (IAS 37, paragraph 59). To the extent that a change in an accounting estimate gives rise to changes in liabilities it shall be recognised by adjusting the carrying amount of the related liability in the period of the change (IAS 8, paragraph 37).

Source: Author's analysis 
In order to support the view that the IASB should consider the classification of the liability as a provision rather than deferred revenue, the effect of recognising the liability as a provision in the illustrative example was examined.

\subsection{Alternative treatment in applying IAS 8 and IAS 37}

The effect on the above example if the principles of IAS 8 and IAS 37 are applied is as follows: the example states that management's expectations regarding the points granted change in the second year. It can therefore be assumed that the expectation at the end of year one remains unchanged. If at the end of year one management still expects that only $80 \%$ of consumers will exchange points granted, the balance of the provision remains unchanged as R50. During year two, management expects that $90 \%$ of the points originally granted will be exchanged. The provision should therefore be increased from R50 to R62.50 in year two.

The journal entries in TABLE 4 below illustrate the accounting entries of the above transaction in the general journal of the grocery retailer if IAS 8 and IAS 37 principles are applied:

TABLE 4: General journal entries of the grocery retailer

\begin{tabular}{|c|c|c|c|}
\hline Date & Journal entry & Debit & Credit \\
\hline \multirow[t]{7}{*}{ Year 1} & Bank & 1000 & \\
\hline & Revenue & & 900 \\
\hline & Provision & & 100 \\
\hline & \multicolumn{3}{|l|}{ (Fair value allocated to points: $R 1.25 \times 80 \% \times 100$ points) } \\
\hline & Provision & 50 & \\
\hline & Revenue & & 50 \\
\hline & (40 points $/ 80$ points $\times$ R100) & & \\
\hline \multirow[t]{6}{*}{ Year 2} & Fair value adjustment / Revenue & 12.50 & \\
\hline & Provision & & 12.50 \\
\hline & $\begin{array}{l}\text { (The fair value of the provision is increased with } \\
\text { estimate.) }\end{array}$ & the change in & accounting \\
\hline & Provision & 51.25 & \\
\hline & Revenue & & 51.25 \\
\hline & $(41$ points $\times R 1.25)$ & & \\
\hline \multirow[t]{3}{*}{ Year 3} & Provision & 11.25 & \\
\hline & Revenue & & 11.25 \\
\hline & (9 points $\times$ R1.25) & & \\
\hline
\end{tabular}

Source: Author's analysis

If the principles of IAS 8 and IAS 37 are applied, the value of the points exchanged in year two now equals the value of the benefits supplied (R51.25). The same applies for the points 
exchanged in year three: the value of the points exchanged equals the value of the benefits supplied (R11.25).

Recognising the liability as a provision the value allocated to the points will reflect the fair value (as required by IFRIC 13) even if a change in expectation occurs in contrast with when the liability is recognised as deferred revenue. The outcome of applying IAS 8 and IAS 37 in the illustrative example provides support that the IASB should consider the classification of the liability as a provision rather than deferred revenue.

If the liability (provision) needs to be adjusted, the question arises whether the contra-entry should be recorded in the revenue account or in the fair value adjustment account. Both of these alternatives will comply with IAS 8 paragraph 36 , which states that the change in estimate should be recognised through profit or loss. The account below shows the revenue account for the three-year period if the change in estimate is accounted in the revenue account:

\begin{tabular}{|c|c|c|c|c|c|}
\hline \multicolumn{6}{|c|}{ Revenue } \\
\hline \multirow{7}{*}{ year 2} & \multirow{5}{*}{ Provision } & \multirow{5}{*}{12.50} & year 1 & Bank & 900.00 \\
\hline & & & year 1 & Provision & 50.00 \\
\hline & & & & & \\
\hline & & & Year 2 & Provision & 51.25 \\
\hline & & & year 3 & Provision & 11.25 \\
\hline & \multirow[t]{2}{*}{ Trade account } & 1000.00 & & & \\
\hline & & 1012.50 & & & 1012.50 \\
\hline
\end{tabular}

If the adjustment is against revenue, the total revenue recognised will still amount to $\mathrm{Rl} 000$, corresponding to the value of the original sale. This treatment is in line with the rationale in IFRIC $13 \mathrm{BC}$ paragraph 16 that a change in expectations does not affect the consideration that the supplier has received for supplying benefits (the consideration was fixed at the time of the initial sale). The revenue figure in year one and year two will be slightly skewed but once all the points are exchanged (as expected) in year three, the total revenue figure equals the original compensation received. Because of this, it is recommended that the change in estimate is recorded in the revenue account rather than in the fair value adjustments account, otherwise the total sales figure will not match the compensation originally received for the sales transaction.

\subsection{Support from Circular 09/06 Transactions giving rise to revenue/ purchases}

To support the above conclusion refer to Circular 09/06 Transactions giving rise to revenue/purchases. Points granted or cash back rewards issued can be viewed as a discount arrangement (Rowley, 2005). Circular 09/06 states that revenue should be measured net of trade discounts and cash discounts (such as rebates). For rebates a change in estimate is also possible. In respect of rebates on a sales transaction, the rebate should be estimated at the time of sale and deducted from revenue. If a change in the estimate occurs, the change should be accounted for against revenue (Wingard, Von Well, Pretorius, Ferreira, Badenhorst, \& Van der Merwe, 2012). To further support the view that the deferred revenue (liability) must be measured 
with reference to the selling price (as per IFRIC 13 and IFRS 13) one can refer to the measuring of the provision for rebate that also refers to the selling price in the underlying sales transaction.

\subsection{Is the fair value measurement in IFRIC 13 consistent with the requirements of IFRS 13 ?}

Many IFRSs allow or require the use of fair value without adequate and consistent guidance on how fair value is to be determined. The objective of IFRS 13 Fair Value Measurement (issued 18 May 2011) is to define the term 'fair value', to set out a framework for measuring fair value and to list disclosure requirements about fair value measurements (IFRS 13, paragraph 1). IFRS 13 applies when another IFRS requires or permits fair value measurement (IFRS 13, paragraph 5) and consequently applies to IFRIC 13.

IFRIC 13 determines that a portion of the consideration received in a revenue transaction where points are granted must be deferred; thus deferred revenue must be measured at the fair value of the future benefits. As discussed earlier, deferred revenue arising in a client loyalty programme transaction meets the definition of a liability. IFRS 13 therefore applies to the fair value measurement of the liability and the IFRS 13 definition of fair value with reference to a liability is considered.

IFRS 13 paragraph 9, together with paragraph 24, defines fair value as the price paid to transfer a liability in an orderly transaction between market participants at the measurement date under current market conditions regardless of whether that price is directly observable or estimated using another valuation technique. The fair value can therefore be defined as the exit price.

IFRS 13 distinguishes between liabilities held by other parties as assets, and liabilities not held by other parties as assets. There is a difference in measuring the fair value of these two categories of liabilities. In a client loyalty programme the points granted give the consumer a right to future benefits. The points earned by the consumer will therefore be an asset in the hands of the consumer, and the first category of liability is applicable.

When a quoted price for the transfer of an identical or a similar liability is not available and the identical item is held by another party as an asset, an entity shall measure the fair value of the liability from the perspective of a market participant that holds the identical item as an asset at the measurement date (IFRS 13, paragraph 37). The fair value of a liability reflects the effect of non-performance risk (including the entity's own credit risk) (IFRS 13, paragraph 42). The entity shall therefore take into account the effect of its own credit risk and any other factors that might influence the likelihood that the obligation will or will not be fulfilled (IFRS 13, paragraph 43).

It can be seen from the above that IFRS 13 and IFRIC 13's guidelines regarding the determination of fair value are aligned with each other. It can be concluded that sufficient changes have been made to IFRIC 13 since issuance in order to include or reflect IFRS 13. TABLE 5 illustrates this. 
TABLE 5: IFRS 13 and IFRIC 13's similar guidelines on determining the fair value of a liability (deferred revenue)

When a quoted price for the transfer of an identical or a similar liability is not available and the identical item is held by another party as an asset, an entity shall measure the fair value of the liability from the perspective of a market participant that holds the identical item as an asset at the measurement date (paragraph 37 ).

The fair value of a liability reflects the effect of non-performance risk (paragraph 42).
If there is not a quoted market price for an identical point, fair value must be measured using another valuation technique. The supplier may measure the fair value of points by reference to the fair value of the benefits they could be exchanged for (AG, paragraph 1). In other words, the value of the points (held as an asset) in the hands of the consumer.

The fair value of the points among other things takes into account non-performance risk ( $A G$, paragraph 2 ).

Source: Author's analysis

The value of the points from the perspective of the supplier (as per IAS 37) equals the cost price of goods or services to be supplied or rendered. The measuring of the provision in terms of IAS 37 correlates with the second category mentioned in IFRS 13, i.e. liabilities not held by other parties as assets. IFRS 13 paragraph 40 states that for liabilities not held by other parties as assets the fair value is measured from the perspective of a market participant that owes the liability. IAS 37 has not been updated to include the first category of liability (liabilities held by other parties as assets).

The value of the points from the perspective of the consumer (as per IFRIC 13) equals the value or selling price of goods or services to be received. IFRIC 13 determines that a part of the consideration received in a revenue transaction on which points are earned must be allocated to the points granted and deferred. For this reason it is more appropriate to measure the liability with reference to the consideration received (in other words, the selling price). IFRIC 13's guideline to measure the liability from the perspective of the consumer (using the selling price) will correctly defer the revenue at the selling price. Therefore, IFRIC 13's guidance in measuring the liability can be accepted as appropriate.

\section{CONCLUSION}

IFRIC 13 determines that a part of the consideration received in a client loyalty programme must be allocated to the points granted and must be measured at fair value (taking into account the number of points expected to be exchanged). The fair value will change with a change in expectation, but IFRIC 13, which classifies the liability as deferred revenue, does not allow any adjustments.

It was found that the deferred revenue arising in a client loyalty programme transaction meets the definition of a provision. If the liability is recognised as a provision, it will result in the following if a change in accounting estimate occurs:

- the value allocate $d$ to the points will always reflect the fair value (as required by IFRIC 13); 
- the revenue recognised in the future will be in line with the value of the points exchanged and the value of the benefits supplied; and

- a more realistic picture of the actual liability at year end in the financial statements of the client loyalty programme supplier.

It can be concluded that the principles of IAS 8 and IAS 37 should be applied and the liability (provision) should be adjusted to accommodate a change in accounting estimate. IFRIC 13's guidance in relation to a change in accounting estimate is not consistent with IAS 37 and IAS 8. There is a discrepancy between IFRIC 13 BC paragraph 16 , which states that the liability should not be adjusted with a change in estimate, and IAS 37 paragraph 59 and IAS 8 paragraph 37, which provide that the provision (liability) needs to be adjusted with a change in estimate.

A further finding was that the IFRIC 13 guidance on how a single-company client loyalty programme should initially account for a client loyalty programme transaction is in line with IFRS 13 and mostly aligned with IAS 37. IFRIC 13 and IFRS 13 both correctly determine that the liability must take into account non-performance risk and must be measured from the perspective of the consumer.

\section{RECOMMENDATIONS}

The IASB is currently compiling a new revenue standard. This standard will replace six existing standards or interpretations, including IAS 18 and IFRIC 13. All comments on the second exposure draft "Revenue from Contracts with costumers" received by 13 March 2012 (Ernst \& Young, 2011:1) are currently under consideration. The principles highlighted in this article could be useful for the formulation of the new revenue standard. It is suggested that the IASB should consider the issues highlighted in this article to prevent any further confusion. In addition, the IASB should formulate clear guidelines regarding the accounting treatment of a single-company client loyalty programme transaction where a change in accounting estimate occurs, to ensure that this is consistent with other standards.

It is recommended that the IASB should consider the possibility of recognising the liability that arises in a client loyalty programme transaction as a provision. It is also recommended that IAS 37 be updated and amended to include or reflect IFRS 13. The following specific shortcomings need attention: IAS 37 should refer to the value of the provision (liability) as the fair value and should state that the liability should take into account non-performance risk. IAS 37 should distinguish between provisions (liabilities) held by other parties as assets and provisions (liabilities) not held by other parties as assets. IAS 37 should stipulate the following measurement criteria for the provisions: For provisions (liabilities) held by other parties as assets the fair value should be measured from the perspective of a market participant that holds the identical item as an asset (IFRS 13, paragraph 37) and provisions (liabilities) not held by other parties as assets the fair value should be measured from the perspective of a market participant that owes the liability (IFRS 13, paragraph 40). Alternatively, if IAS 37 refers to the value of the provision (liability) as the fair value it will automatically refer to IFRS 13 for the measurement of a provision. 


\section{LIST OF REFERENCES}

Brink, SM. (2012). Inkomstebelastinghantering van kliëntelojaliteitsprogramtransaksie in SuidAfrika. Journal of Economic \& Financial Sciences, 5(2), pp. 437-458.

Conradie, B. (bruce@worldwideworx.com). 17 June 2011. RE: Bruce Conradie. Email to author.

Conradie, B. (2007). Value in loyalty programmes 2007: A survey of South African rewards-based loyalty programmes. Razor's Edge Business Intelligence.

Ernst \& Young, (2011). IASB and FASB revised revenue recognition proposals. [Online] Available: http://www.ey.com/Publication/vwLUAssets/IFRS_Development_Issue_18/\$FIE/IFRS\%20Developme nts\%20lssue\%2018_1111.pdf. (Accessed 5 June 2012)

Ernst \& Young, (2012). The revised revenue recognition proposal - retail and consumer products. [Online] Available: http://www.ey.com/Publication/vwLUAssets/Applying_IFRS_in_

Retail_and_Consumer_Products/\$FILE/Applying\%20IFRS\%20$\% 20$ Revenue $\% 20$ recognition $\% 20$ proposal_retail\%20and\%20consumer $\% 20$ products.pdf. (Accessed 5 June 2012)

IAS 8, Accounting Policies, Changes in Accounting Estimates and Errors. (1993). International Accounting Standards Board (IASB). London.

IAS 18, Revenue. (1993). International Accounting Standards Board (IASB). London.

IAS 37, Provisions, Contingent Liabilities and Contingent Assets. (1998). International Accounting Standards Board (IASB). London.

IFRIC 13, Customer Loyalty Programmes. (2007). International Accounting Standards Board (IASB). London.

IFRS 13, Fair Value Measurement. (2011). International Accounting Standards Board (IASB). London.

KPMG, (2011). New on the horizon: Revenue from contracts with customers. [Online] Available:

http://www.kpmg.com/Global/en/IssuesAndInsights/ArticlesPublications/New-on-the-

Horizon/Documents/NOTH-revenue-from-contracts-a.pdf. (Accessed 19 0ctober 2012)

Lamareaux, M.G. 2012. A new system for recognizing revenue. Journal of accountancy 213.1 (Jan 2012): $30-35,10$.

Liu, Y. (2007). The long-term impact of loyalty programmes on consumer purchase behaviour and loyalty, Journal of Marketing, [Online] Available:

http://web.ebscohost.com.ez.sun.ac.za/ehost/pdfviewer/pdfviewer?sid=eb9lde90-b5da-4e0fbb71-4a9965cla313\%40sessionmgrl1\&vid=5\&hid=17. (Accessed 19 April 2011)

Maharaj, A. (2008). Awareness perceptions and effects of customer loyalty programmes within the retail sector of the Durban Metropolitan area. Unpublished master's dissertation. South Africa: University of South Africa.

PricewaterhouseCoopers. (2009). Making sense of a complex world IFRIC 13 - Customer loyalty programmes [Online] Available: http://www.pwc.com/en_GX/gx/communications/pdf/IFRIC13.pdf. (Accessed 11 May 2012)

Republic of South Africa. (2008). Consumer Protection Act No.68 of 2008. Cape Town: Gazette 526 (32186):1-94. 
Rowley, J. (2005). Customer relationship management through the Tesco Clubcard loyalty scheme. International Journal of Retail \& Distribution Management, 33(3):194-206.

Maharaj, A. (2008). Awareness perceptions and effects of customer loyalty programmes within the retail sector of the Durban Metropolitan area. Unpublished master's dissertation. South Africa: University of South Africa.

PricewaterhouseCoopers. (2009). Making sense of a complex world IFRIC 13 - Customer loyalty programmes [Online]. Available: http://www.pwc.com/en_GX/gX/communications/pdf/IFRICl3.pdf. (Accessed 11 May 2012)

Republic of South Africa. (2008). Consumer Protection Act No.68 of 2008. Cape Town: Gazette 526 (32186):1-94.

Rowley, J. (2005). Customer relationship management through the Tesco Clubcard loyalty scheme. International Journal of Retail \& Distribution Management, 33(3):194-206.

Travel wires. (2011). Terms and conditions distort loyalty programmes - Protea Hospitality.

[Online].Available: http://www.travelwires.com/wp/2011/03/\%६2\%80\%9Cterms-

conditions\%E2\%80\%9D-distort/. (Accessed 8 April 2011)

Wingard, H.C., Von Well, R., Pretorius, D. Ferreira, P.H., Badenhorst, W.M. \& Van der Merwe, D. (2012). GAAP handbook Financial Accounting and Reporting Practice. Durban: Lexis Nexis. 
